\title{
DETECTION OF MYCOPLASMA HYOPNEUMONIAE BY POLYMERASE CHAIN REACTION IN SWINE PRESENTING RESPIRATORY PROBLEMS
}

\author{
Yamaguti, M. ${ }^{*}$; Muller, E.E. ${ }^{1}$; Piffer, A.I. ${ }^{2}$ Kich, J.D. ${ }^{2}$; Klein, C.S. ${ }^{2}$; Kuchiishi, S.S. ${ }^{3}$ \\ ${ }^{1}$ Universidade Estadual de Londrina, Campus Universitário, Londrina, PR, Brasil; ${ }^{2}$ Embrapa Suínos e Aves, Concórdia, SC, \\ Brasil; ${ }^{3}$ Universidade Estadual de São Paulo, Jaboticabal, SP, Brasil.
}

Submitted: April 09, 2007; Returned to authors for corrections: January 23, 2008; Approved: July 04, 2008.

\begin{abstract}
Since Mycoplasma hyopneumoniae isolation in appropriate media is a difficult task and impractical for daily routine diagnostics, Nested-PCR (N-PCR) techniques are currently used to improve the direct diagnostic sensitivity of Swine Enzootic Pneumonia. In a first experiment, this paper describes a N-PCR technique optimization based on three variables: different sampling sites, sample transport media, and DNA extraction methods, using eight pigs. Based on the optimization results, a second experiment was conducted for testing validity using 40 animals. In conclusion, the obtained results of the N-PCR optimization and validation allow us to recommend this test as a routine monitoring diagnostic method for Mycoplasma hyopneumoniae infection in swine herds.
\end{abstract}

Key-words: Swine Enzootic Pneumonia, Mycoplasma hyopneumoniae, diagnosis, Nested- PCR.

\section{INTRODUÇÃO}

Mycoplasma hyopneumoniae (M. hyopneumoniae) is the primary etiological agent of the Swine Enzootic Pneumonia (SEP), that leads to a non-productive cough, mild fever, weight gain loss, high morbidity, and low mortality (12,17). SEP is considered one of the most worldwide common respiratory diseases and is responsible for high economic loss due to secondary infections. Its diagnosis can be performed by anamnesis, clinical signs described above, and gross lesions detected at slaughterhouses such as hepatized lung areas. However, since several microorganisms may cause similar alterations, it is not possible to state that $M$. hyopneumoniae is the causative agent of such lesions and clinical signs $(8,12,23,27)$.

Although definitive PES diagnostic can be obtained by microorganism isolation, this technique is laborious and requires at least 15 days for colony growth. These features make isolation procedures impractical for daily routine diagnostis. Antibody identification by ELISA or IFI is a diagnostic alternative, but it may show non-specific reactions with other porcine mycoplasmas, such as M. hyorhinis and M. flocculare $(15,19,23)$.
Nowadays, fastidious microorganisms have been detected by molecular biology techniques, such as DNA or RNA hybridization and Polymerase Chain Reaction (PCR). These techniques are faster and more specific for microorganism detection (6); and since mycoplasmas isolation is impractical in daily routine of several laboratories, PCR assay can improve the sensitivity of their direct diagnostic. Accordingly, this technique may be feasible to apply for detection of $M$. hyopneumoniae from pig clinical samples such as tracheal washings nasal swabs, and lung fragments $(2,7,13,18,28)$.

The Nested-PCR (N-PCR) is a variation of the standard PCR that involves second amplification of the PCR product, using internal specific primers complementary to the first amplification nucleotide sequence (3). According to TANG et al. (1997), this second amplification increases the PCR sensitivity because of the double amplification process, and also verifies the first reaction specificity.

Thus, this paper proposes the optimization of a N-PCR technique for the detection of 16S rRNA gene fragments of $M$. hyopneumoniae through the evaluation of different sampling sites, sample transport media, and DNA extraction methods.

*Corresponding Author. Mailing address: Universidade Estadual de Londrina, Campus Universitário Cx. Postal, 600, CEP 86051-970, Londrina, PR.;.; E-mail: yamau@usp.br 


\section{MATERIALAND METHODS}

In a first experiment, eight pigs at 10 to 12 weeks old from Unidade Demonstrativa de Suínos do CNPSA- EMBRAPA were selected. They showed SEP clinical signs, no mycoplasma vaccination history, and were positive by ELISA (CNPSAEMBRAPA) for M. hyopneumoniae infection. These animals were used to analyze two biological samples, nasal and tonsil swabs; two sample transport media; and five DNA extraction methods.

Initially, $10 \mathrm{~mL}$ of blood were collected from each animal by venipuncuture of the anterior cava vein using disposable syringe and $80 \mathrm{X} 10$ needles. After clot formation, blood samples were centrifuged for five minutes at $3000 \mathrm{x} \mathrm{g}$. The obtained serum was stored at $-20^{\circ} \mathrm{C}$ until ELISA procedures.

A total of 136 swabs (tonsil and nasal) were collected from the eight animals in a period of 14 days with a 4 day interval. The swabs were stored in two sample transport media, 68 in FRIIS media (34 tonsil swabs and 34 nasal swabs) (10) and 68 in saline ( $\mathrm{NaCl} 0.85 \%$ ) (34 tonsil swabs and 34 nasal swabs). All samples were stored in microtubes with $0.5 \mathrm{~mL}$ of media, inside a box containing ice, and sent to the laboratory. Then, the samples were vortex mixed and $200 \mu 1$ were used for DNA extraction. For N-PCR optimization, five DNA extraction methods were evaluated:A) silica/guanidinium thiocyanate (5); B) boiling/ice (9); C) triton X 100/ proteinase K (21); D) phenol/chloroform (7) E) phenol/chloroform / isoamyl alchool (22). A total of $50 \mu 1$ of the extracted DNA was stored in microtubes at $-20^{\circ} \mathrm{C}$ until PCR assays.

In a second experiment, 40 pigs of 10 to 12 weeks old presenting coughing and sneezing were used. They were from a farm with a history of lung lesions at the slaughterhouse (hepatized areas) and positive results for M. hyopneumoniae serology by ELISA(CNPSA-EMBRAPA).

Blood samples for ELISA were also collected as described in the first experiment. The swabs were obtained from a single visit to the farm. Two tonsil and two nasal swabs were collected from each animal for a total of 160 swabs. From the 80 nasal swabs, 40 swabs were stored in saline and 40 in FRIIS media. The same procedures were adopted for the 80 tonsil swabs. Sample conservation and transportation were followed as described in the first experiment.

Based on the results of the first experiment, the silica/ guanidinium thiocyanate method (Boom) was used for the tonsil and nasal swabs stored in saline and, the boiling/ice method (Fan) was used for the tonsil and nasal swabs stored in FRIIS media.

The specie-specific primers utilized in this study were complementary to conserved mycoplasma sequences of the 16SrRNA gene. The external primers Mh-up and Mh-do (PCR), described by MATSSON et al. (1995), and the internal primers NMh-up and NMh-do (N-PCR), described by CALSAMIGLIA et al. (1999) are presented in Table 1. All primers were synthesized by Invitrogen ${ }^{\circledR}$ do Brasil.

During the PCR optimization, different annealing temperatures for external and internal primers, and primers and $\mathrm{MgCl} 2$ concentrations were analyzed in independent reactions. These parameters were analyzed keeping Taq DNA polymerase, buffer PCR and dNTPs in constant concentrations.

For the PCR assay, $2 \mu \mathrm{l}$ of DNA sample were added in a $20 \mu \mathrm{l}$ PCR-MIX containing one unit of Taq DNA polymerase, 1 X PCR buffer $(20 \mathrm{mM}$ Tris $\mathrm{HCl} \mathrm{pH} 8.4$ and $50 \mathrm{mM} \mathrm{KCl})$, and $1 \mathrm{mM}$ of dNTP's. Primers and $\mathrm{MgCl} 2$ concentrations varied according to the type of the primer. For the N-PCR assay, the volume of the product of the first amplification and N-PCR MIX were $1 \mu 1$ and $20 \mu 1$, respectively. MgCL2 concentrations of 2, 2.5, 3, and $3.5 \mathrm{mM}$ for internal and external primers were tested in separate reactions. Different primer concentrations were also evaluated $(2,5,10,15,20,25$, and $30 \mathrm{pmol})$. For evaluation of the annealing temperature, a gradient of temperature was used with thermal amplitude of $7^{\circ} \mathrm{C}$ around the average temperature of $52^{\circ} \mathrm{C}$.

Amplification processes were taken in a thermocycle (Mastercycler gradient 5331 - Eppendorf) according to the following conditions: $94^{\circ} \mathrm{C}$ for 4 minutes; 35 cycles at $95^{\circ} \mathrm{C}$ for 45 seconds, gradient of temperature for 1 minute, $72^{\circ} \mathrm{C}$ for 2 minutes; followed by a final extension at $72^{\circ} \mathrm{C}$ for 5 minutes. For each amplification, negative (ultrapure water) and positive ( $M$. hyopneumoniae - ATCC 25934) controls were added.

A total of $10 \mu \mathrm{l}$ of each PCR product and a $100 \mathrm{bp}$ molecular weight (Amersham Pharmacia Biotech ${ }^{\circledR}$ ) were separated by electrophoresis in a $2 \%$ agarose gel containing ethidium bromide, $0.5 \mu \mathrm{g} / \mathrm{ml}$ in TEB 1 X buffer (Tris $0.1 \mathrm{M} ; 0.5 \mathrm{MEDTApH}$ 8.0; boric acid, $\mathrm{pH} 6.0$ ), under constant voltage of $100 \mathrm{~V}$ for 50 minutes. The gels were viewed and photographed under UV light using a Vilber Lourmat imaging system.

The reference strain M. hyopneumoniae (ATCC 25934) was used for the sensitivity test (M. hyopneumoniae detection limit). It was cultured in FRIIS media at $37^{\circ} \mathrm{C}$ for 10 days and diluted in the same media until $10^{-8}$. A total of $100 \mu$ l of each dilution was plated in FRIIS media plates and incubated at $37^{\circ} \mathrm{C}$ in microaerophilia. After 10 days of incubation, Colony Forming Units (CFU) were counted for DNA extraction and PCR and NPCR assays.

The spectrophotometer was used to determine the sensitivity using $1 \mathrm{~mL}$ of the $M$. hyopneumoniae initial culture. DNA extraction was performed by Boom method and the DNA was quantified in $\mu \mathrm{g} / \mu \mathrm{l}$.

N-PCR specificity was evaluated using commonly found microorganisms of the swine respiratory tract: $M$. hyopneumoniae (ATCC 25934), M. hyorhinis (ATCC 17981), M. hyosynoviae (ATCC 25591), M. flocculare (MF) (ATCC 27716), Actinobacillus pleuropneumoniae serotype 5B cepa L20, Haemophilus parasuis S1 $\left(\mathrm{Nr}_{4} \mathrm{p}_{2}\right)$, Haemophilus parasuis S2 (SW140 $\left.\mathrm{p}_{2}\right)$, Pasteurella multocida, and Bordetella 
Table 1. Primers used for fragment amplification of the 16S rRNA gene of Mycoplasma hyopneumoniae by Nested-PCR.

\begin{tabular}{lccc}
\hline External primers & Sequence & Position & Fragment size \\
\hline Mh up (forward) & 5'GAGCCT TCAAGC TTCACCAAGA3' & $212-233$ & $649 \mathrm{bp}$ \\
Mh do (reverse) & 5'TGT GTT AGT GAC TTT TGC CAC C 3' & $839-860$ & \\
Internal primers & & & \\
NMh up (forward) & 5'ACTAGA TAG GAAATG CTC TAG T3' & $463-484$ & $352 \mathrm{bp}$ \\
NMh do (reverse) & 5'GTG GACTAC CAGGGTATC T' & $797-815$ & \\
\hline
\end{tabular}

bronchiseptica.Pasteurella and Bordetella strains were field isolates of Embrapa Suínos e Aves.

The DNA amplified segment was sequenced using KIT "Big DyeTM Terminator Cycle Sequencing Ready Reaction Kit Applied Biosystems do Brasil Ltda". The N-PCR product was precipitated using $3 \mathrm{M}$ sodium acetate and isopropanol for 12 hours, centrifuged at $21000 \mathrm{Xg}$ for 10 minutes. Then supernatant was discarded, and the sediment was suspended in TE buffer (10 mM Tris-HCl pH 7.5, and $1 \mathrm{mM}$ EDTA). After precipitation, the DNA was quantified by comparison to the Lambda DNA EcoRI Hind III digest $\left(\mathrm{SIGMA}^{\circledR}\right)$ molecular weight in $0.8 \%$ agarose gel.

A total of $20 \mathrm{ng}$ of the DNA sample, 5 pmol of primer NMhup, $8 \mu$ l of the kit Big Dye, and $12 \mu$ l of ultrapure water was used for the sequencing reaction. The program profile was: 25 cycles at $96^{\circ} \mathrm{C}$ for 30 seconds, $50^{\circ} \mathrm{C}$ for 15 seconds, $60^{\circ} \mathrm{C}$ for 4 minutes, followed by a final step at $4^{\circ} \mathrm{C}$ for 15 minutes. After sequencing reaction, the product was precipitated using isopropanol and $75 \%$ ethanol. The precipitate was dried and suspended in $6 \frac{1}{4} 1$ of "Loading buffer" and the interpretation performed in a ABI PRISMA 377 DNA SEQUENCER (Elmer Perking) system. The sequence alignment was done using a BLAST program (2006).

The N-PCR results and variables (sampling sites, sample transport media, and DNA extraction methods) were evaluated using $\chi 2$ test by CATMOD models. The statistical software SAS (2001) was used.

\section{RESULTS AND DISCUSSION}

All the MgCL2 concentrations resulted in predicted N-PCR products. Accordingly, the concentrations of $2.0 \mathrm{mM}$ for the PCR and $2.5 \mathrm{mM}$ for the N-PCR were adopted. The best annealing temperatures, without inespecific bands and with appropriate amplifications, were $65.5^{\circ} \mathrm{C}$ and $59.5^{\circ} \mathrm{C}$ for PCR and N-PCR assays, respectively.

External and internal primer concentrations evaluation did not show visual differences from 10 to 20 pmol. Thus, the chosen concentration was 10 pmol for the PCR and N-PCR.

Five DNA extraction methods, two biological samples, and two sample transport media were evaluated in the first experiment. Different DNA extraction methods have been described in the literature with a high variability in sampling sites and sample conservation for N-PCR optimization $(2,3,7,25)$. In the present study, DNA extraction by Boom method showed better results for nasal and tonsil swabs stored in saline; and the Fan method showed better results for nasal and tonsil swabs stored in FRIIS media (Table 2).

In the second experiment, N-PCR results were analyzed using 160 swabs from 40 animals and the following variables: sampling sites, sample transport media, and DNA extraction methods (Table 3). Although 38 (95.0\%) out of the 40 tonsil samples in saline presented positive results in N-PCR and only $32(80.0 \%)$ of the nasal samples in saline showed positive results, these results were not statistically different $(\mathrm{p}<5 \%)$ using the Boom DNA extraction method. However, using the Fan technique, there was a statistical difference $(\mathrm{p}<5 \%)$ between the $29(72.5 \%)$ positive tonsil swabs and $06(15.0 \%)$ positive nasal swabs. Although statistical difference could not be observed between Fan method using nasal swabs in saline and Boom using tonsil swabs in FRIIS media, Boom technique presented better results than Fan $(p<5 \%)$ because of higher detection of positive results.

Comparing tonsil and nasal swabs, the number of positive samples was higher using tonsil swabs. This fact may be explained by possible blood contamination due to nasal lesions

Table 2. Number of positive samples of N-PCR collected from 8 finishing pigs using five DNA extraction methods, two types of sample transport media, and two types of swabs.

\begin{tabular}{ccccc}
\hline Media & \multicolumn{2}{c}{ FRIIS } & \multicolumn{2}{c}{ Saline } \\
\hline Swab & & & & \\
Extraction method & Tonsil & Nasal & Tonsil & Nasal \\
\hline BOOM & 3 & 4 & 6 & 7 \\
FAN & 7 & 3 & 5 & 2 \\
CBIOT & 6 & 3 & 3 & 4 \\
CALSAMIGLIA** & 2 & 1 & 3 & 2 \\
SAMBROOK** & 2 & 0 & 1 & 0 \\
\hline Total & 20 & 11 & 18 & 15 \\
\hline
\end{tabular}

*T: Tonsil; N: Nasal; **only five pigs were used. 
during the sampling and/or existing lesions caused by powder, microorganisms and other factors. This contamination may lead to reaction inhibition and/or increase in DNA from other sources than mycoplasma (24). Tonsil swab reduces the occurrence of lesions during the sampling and decreases the number of false negatives. BACCARO et al., (1999) have also observed a higher number of M. hyopneumoniae positive animals using tonsil swab when compared to nasal sample.

Several studies have suggested different sampling sites using N-PCR, such as lung fragments, tracheobronchial washings, and nasal swabs $(3,7,16)$. In the present study, tonsil swab was a feasible sampling method for pigs, without the need of anesthesia or post mortem sampling.

Statistical analyses of DNA extraction methods presented in Table 3 show the superiority of the Boom technique when compared to Fan, independently of the sampling site.

$M$. hyopneumoniae viability in swabs stored in saline was greater when compared to swabs stored in FRIIS media (Table 3 ). FRIIS media was used in the present study due to recommendations of several authors for $M$. hyopneumoniae isolation $(10,11,14,18)$. BAUSMEISTER et al. (1998) have found low sensitivity of the PCR using bronchoalveolar samples cultivated in FRIIS media, probably because of media component interference on PCR, especially the serum.

The DNA detection limit of the N-PCR using a spectrophotomer was $8 \times 10^{-8} \mu \mathrm{g} / \mu \mathrm{l}$ (dilution $10^{-5}$, Fig. 1), or 80 fentograms (fg) of DNA, corresponding to 80 microorganisms. Fentograms determination was reported by VERDIN et al. (2000), in which, $1 \mathrm{fg}$ was equivalent to one microorganism, according to the mean genome size of mycoplasmas. CALSAMIGLIA et al. (1999) used the same primers of the present study and also found $80 \mathrm{fg}$ sensitivity.

Sensitivity according to CFU counts was approximately 0.9 $\mathrm{CFU} / \mu 1$. According to (20), one CFU ranged from 100 to 1000 microorganisms. The N-PCR sensibility evaluation by spectrophotometer is more accurate than colony counting, since microorganisms equivalence is close to the true microorganism number than the value obtained by CFU.

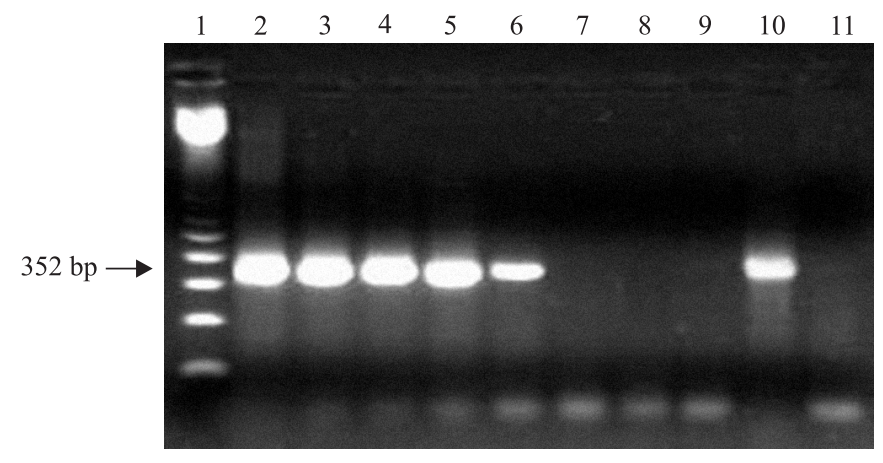

Figura 1. Sensitivity test results of N-PCR technique used for DNA detection of M. hyopneumoniae 16SrRNA gene: 1- 100bp ladder (Amersham pharmacia biotech); from 2 to 9- DNA dilutions (Boom DNA extraction method) in ultrapure water from $10^{-1}$ to $10^{-8} ; 10$ - Positive control (M. hyopneumoniae - ATCC 25934); 11- N-PCR negative control.

This fact is reported by several authors that determine NPCR sensitivity, such as VERDIM et al. (2000) with a sensitivity of $1 \mathrm{fg}$ and CALSAMIGLIA et al. (1999) with a $80 \mathrm{fg}$ sensitivity.

The specificity test showed that only the ATCC $M$. hyopneumoniae strain present a predicted band of approximately $352 \mathrm{bp}$. No other amplification fragment was observed using other microorganisms (Fig. 2).

Although M. flocculare and M. hyopneumoniae have shown high 16S rRNA sequence homology, primer sets used in the present study were highly specific for $M$. hyopneumoniae detection. Both 16S rRNA sequences were analyzed using BLAST program and resulted in 95\% homology. The $M$. hyopneumoniae DNA region amplified by 352 bp N-PCR has four different base pairs when compared to $M$. flocculare. Thus, PCR primers for $M$. hyopneumoniae are complementary to a sequence that can be differentiated from $M$. flocculare, and are highly specific for M. hyopneumoniae detection (7).

The N-PCR amplified product was sequenced using $M$. hyopneumoniae specific primer and showed a $99 \%$ similarity

Tabela 3. Results obtained by N-PCR of samples collected from 40 pigs respiratory problems; considering sampling sites, sample transport media, and DNA extracion method.

\begin{tabular}{cccccc}
\hline & & & \multicolumn{2}{c}{ Results } & \multirow{2}{*}{$\chi^{2 *}$ Test } \\
\cline { 4 - 4 } Extraction & Transport media & Sampling site & Positives N (\%) & Negatives N(\%) & \\
\hline Boom & Saline & Tonsil & $38(95.0)$ & $02(05.0)$ & a \\
Boom & Saline & Nasal & $32(80.0)$ & $08(20.0)$ & ab \\
Fan & FRIIS & Tonsil & $29(72.5)$ & $11(27.5)$ & $\mathrm{b}$ \\
Fan & FRIIS & Nasal & $06(15.0)$ & $34(85.0)$ & $\mathrm{c}$ \\
\hline
\end{tabular}

*Statistical difference on standardization tests using the CONTRATE test $\chi^{2}\left(\mathrm{p}<5 \%\right.$ ) "Catmod SAS. Equal letters on the $\chi^{2} *$ Test collumn indicate no significant difference. 


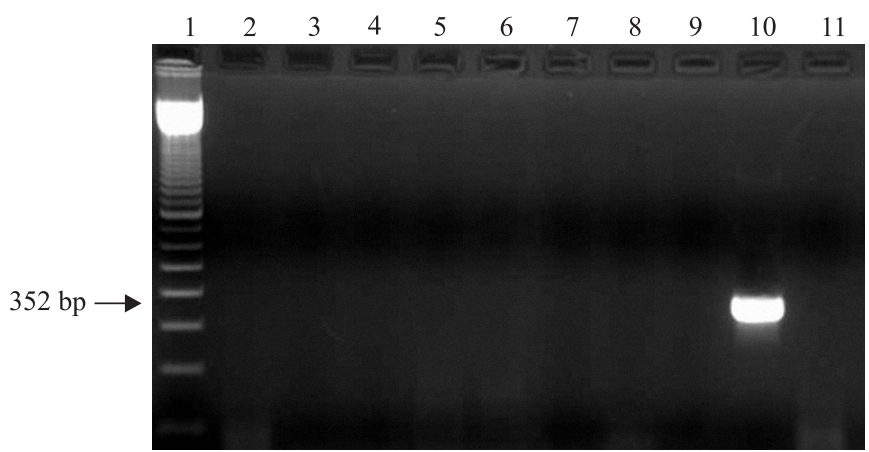

Figure 2. Specificity test results of N-PCR technique used for DNA detection of M. hyopneumoniae 16SrRNA gene. 1- 100 bp ladder (Amersham pharmacia biotech); 2- Mycoplasma hyosynoviae; 3- Mycoplasma hyorhinis; 4- Mycoplasma flocculare; 5- Haemophilus parasuis S1; 6- Haemophilus parasuis S2; 7- Pasteurela multocida; 8- Actinobacillus pleuropneumoniae; 9- Bordetella bronchiseptica; 10Mycoplasma hyopneumoniae; 11- N-PCR negative control.

with the M. hyopneumoniae 16S rRNA sequence deposited in GenBank(Y00149).

The present study showed good N-PCR optimization results for partial detection of M. hyopneumoniae 16S rRNA gene from field samples. Biological samples obtained from tonsil swabs, stored in saline, and submitted to Boom DNA extraction method have shown superior results and are recommended as the best option for SEP diagnostic by NPCR. Moreover, they can be considered a promising method for monitoring $M$. hyopneumoniae infections in swine herds.

Specific media are indicated for the cultivation of mycoplasmas. In order to increase the sensibility of the culture technique some procedures may be followed: addition of antibiotics to the culture media, ten-fold serial dilutions (until $10^{-5}$ ), and over two-week incubation period. However, these recommendations may increase the cost and the time necessary for a disease diagnostic. In this study, saline as transport media for clinical samples swabs resulted in a higher sensibility for mycoplasma detection when compared to specific mycoplasma media; thus, saline solution may be recommended as a transport media for the samples described herein.

\section{RESUMO}

\section{Detecção do mycoplasma hyopneumoniae pela reação em cadeia da polimerase em suínos apresentando problemas respiratórios}

A Nested-PCR (N-PCR) tem como objetivo melhorar a sensibilidade do diagnóstico direto da Pneumonia Enzoótica
Suína, pois o isolamento do Mycoplasma hyopneumoniae é trabalhoso tornando-se inviável na rotina. Neste trabalho, foi realizado um projeto piloto para a otimização da técnica de NPCR, utilizando três variáveis: tipo de amostra biológica, meio de transporte da amostra e método de extração do DNA, utilizando oito animais. Os resultados obtidos foram empregados no segundo experimento para a validação do teste utilizando 40 animais. Os resultados obtidos, pela otimização da N-PCR, neste trabalho, permite sugerir esta prova como método de diagnóstico de rotina no monitoramento das infecções por Mycoplasma hyopneumoniae em granjas de suínos.

Palavras-chaves: Pneumonia Enzoótica Suína, Mycoplasma hyopneumoniae, diagnóstico, Nested-PCR.

\section{REFERENCES}

1. Baccaro, M.R.; Moreno, A.M.; Timenetsky, J. (1999). Detecção de Mycoplasma hyopneumoniae através da PCR em suínos. In CONGRESSO BRASILEIRO DE VETERINÁRIOS ESPECIALISTAS EM SUÍNOS, 9., 1999, Belo Horizonte. Anais. Belo Horizonte, p. 163-164.

2. Bausmeister, A.K.; Runge, M.; Ganter, M.; Feenstra, A.A.; Delbeck, F.; Kirchhoff, H. (1998). Detection of Mycoplasma hyopneumoniae in Bronchoalveolar Lavage Fluids of Pigs by PCR. J. Clin. Microbiol., v. 36, n. 7, p. 1984-1988.

3. Blanchard, B.; Kobisch, M.; Bove J.M.; Saillard, C. (1996) Polymerase chain reaction for Mycoplasma hyopneumoniae detection in tracheobronchiolar washings from pigs. Mol. Cell. Prob., v. 10, p. $15-20$.

4. Blastn 2.2.5 (www.ncbi.nlm.nih.gov/blast/BLAST). Acessado (Nov $16,2002)$

5. Boom, R.; Sol, C.J.A.; Salimans, M.M.M.; Jansen, C.L.; WertheimVan Dillen, P.M.E.; Van Der Noordaa, J. (1990). Rapid and simple method for purification of nucleic acids. J. Clin. Microbiol., v. 28, n. 3, p. 495-503.

6. Buzinhani, M. (2001). Detecção de micoplasmas em fêmeas bovinas apresentando distúrbios reprodutivos por meio de cultivo e reação em cadeia da polimerase. $88 \mathrm{f}$ (Ph.D. Dissertação. Instituto de Ciências Biomédicas, USP).

7. Calsamiglia, M.; Pijoan, C.; Trigo, A. (1999). Application of a nested polymerase chain reaction assay to detect Mycoplasma hyopneumoniae from nasal swabs. J. Vet. Diag. Invest., v. 11, p. 246-251.

8. Christensen, G.; Mousing, J. (1992). Respiratory system. In: Leman, A.D.; Straw, B.E.; Mengeling, W.L.; D’Allaire, S.; Taylor, D.J.; Diseases of Swine, 7th edition, Iowa State University Press, Ames. 1021 p.

9. Fan, H.H.; Kleven, S.H.; Jackwood, M.W. (1995). Application of polymerase chain reaction with arbitrary to strain identification of Mycoplasma gallisepticum. Avi. Dis., v. 39, p. 729-735.

10. Friis, N.F. (1971). Mycoplasmas cultivated from the respiratory tract of Danish pigs. Acta Vet. Scand., n. 12, p. 69-79.

11. Irigoyen, L.F.; Van Alstine, W.; Turek, J. (1998). Ultrastructural observation of the airways of recovered and susceptible pigs after inoculation with Mycoplasma hyopneumoniae. Pesq. Vet. Bras., v. 18 , n. 1, p. 1-7.

12. Kobisch, M. (1997). Doenças respiratórias dos suínos: Mycoplasma hyopneumoniae, agente da pneumonia enzoótica. A Hora Veterinária, v. 17, n. 99, p. $15-18$.

13. Kurth, K.T.; Hsu, T.; Snook, E.R.; Thacker, E.L.; Thacker, B.J.; Minion, F.C. (2002). Use of a Mycoplasma hyopneumoniae nested 
polymerase chain reaction test to determine the optimal sampling sites in swine. J. Vet. Diagn. Invest., v. 14, p. 463-469.

14. Lin, J.H.; Chen, S.P.; Yeh, K.S.; Weng, S.N. (2006). Mycoplasma hyorhinis in Taiwan: Diagnosis and isolation of swine penumonia pathogen. Vet. Microbiol., v. 115, p. 111-116.

15. Maes, D.; Verdonck, M.; Deluyker, H.; Kruif, A. (1996). Enzootic pneumonia in pigs. Vet. Quart., v. 18, n. 3, p. 104-109.

16. Mattsson, J.G.; Bergstrom, K.; Wallgreen, P.; Johansson, K.E. (1995) Detection of Mycoplasma hyopneumoniae in nose swabs from pigs by in vitro amplification of the 16S rRNA gene. J. Clin. Microbiol., v. 33 , p. $893-897$.

17. Morrison, R.B.; Pijoan, C.; Leman, A.D. (1986). Association between enzootic pneumonia and performance. Pig News and Information, n. 7 , p. 23-30.

18. Otagiri, Y.; Asai, T.; Okada, M.; Uto, T.; Yazawa, S.; Hiraki, H.; Shibata, I.; Sato, S. (2005). Detection of Mycoplasma hyopneumoniae in lung and nasal swab samples from pigs by nested PCR and culture methods. J. Vet. Med. Sci., v. 67, n. 8, p. 801-805.

19. Piffer, I.A. (1983). Pneumonia enzoótica dos suínos. Concórdia, SC, EMBRAPA - CNPSA, (EMBRAPA-CNPSA, Circular técnico 5), $23 \mathrm{p}$.

20. Razin, S. (1985). Molecular biology and of Mycoplasmas (Mollicutes). Microbiol. Rev., v. 49, n. 4, p. 419-455.

21. Rychlik, I.; Van Kesteren, L.; Cardova, L.; Svestkova, A.; Martinkova, R.; Sisak, F. (1999). Rapid detection of Salmonella in field samples by nested polymerase chain reaction. Lett. Appl. Microbiol., v. 29, n. $4,269-272$.

22. Sambrook, J.; Fritsch, E.F.; Maniatis, T. (1989). Analysis and Cloning of Eukaryotic Genomic DNA. In: Molecular Cloning: A Laboratory Manual. 2o ed., Cold Spring Harbor Laboratory Press, v. 3, p. 9.169.19 .

23. Sobestiansky, J.; Matos, M.P.C.; Hirose, F. (2001). Pneumonia Enzoótica Suína: prevalência, impacto econômico, fatores de risco e estratégias de controle. 44p. Goiânia: Art 3 Impressões Especiais.

24. Soini, H.; Skurnik, M.; Lippo, K.; Tala, E.; Viljanen, M.K. (1992). Detection and identification of mycobacteria by amplification of a segment of the gene coding the 32 kilodalton protein. J. Clin. Microbiol., v. 30, p. 2025-2028.

25. Stemke, G.W. (1997). Gene amplification (PCR) to detect and differentiate mycoplasmas in porcine mycoplasmal pneumonia. Lett. Appl. Microbiol., n. 25, p. 327-330.

26. Tang, Y.W.; Pocop, G.W.; Persing, D.H. (1997). Molecular diagnostic of infectious diseases. Acta Vet. Hung., v. 43, n. 11, p. 2021-2038.

27. Tracker, E.; Halbur, P.; Ross, R.; Thanawongnuweck, R.; Tracker, B. (1999). Mycoplasma hyopneumoniae potentiation and respiratory syndrome virus- induced pneumonia. J. Clin. Microbiol., v. 37, p. 620-627.

28. Verdin, E.; Saillard, C.; Labbe, A.; Bove, J.M.; Kobisch, M. (2000). A nested PCR assay for the detection of Mycoplasma hyopneumoniae in tracheobronchiolar washings from pigs. Vet. Microbiol., v. 76, p. 31-40. 